\title{
Effect of Simvastatin on the Skeletal Muscles of Senile Male Albino Rats and Possible Protective Role of L-Carnitine. A Histological Study
}

\section{Original Article}

\author{
Mervat S. Mehanna ${ }^{1}$, Ezz Eldeen A. Abdallah ${ }^{2}$, Fatma Alzahraa N. Al-Shahed, \\ and Hagar W. Al-Azab
}

Department of Histology and Cell Biology, Faculty of Medicine, Al-Azhar University ${ }^{\text {ICairo, }}$ ${ }^{2}$ Damietta, Egypt

\begin{abstract}
Background: Hyperlipidemia is a disorder in metabolism which means an abnormal increase in levels of lipids (as cholesterol) and lipid-protein in the blood. It is one of the risk factors that mainly cause atherosclerosis, myocardial infarction, coronary heart disease, cerebral stroke, and renal failure. Simvastatin $(S)$ is one of the most prescribed drugs frequently all over the world due to its excellent performance as hypolipidemic and its relatively low price. L-carnitine (LC) is a nutritional supplement supporting with clinical challenges such as dyslipidemia, anorexia \& physical performance. This study aimed to evaluate the protective role of LC on the skeletal muscle of hyperlipidemic rats treated with (S).

Materials and Methods: Thirty senile male albino rats were used, divided into five equal groups as follows: control group (GI) and the other four groups were fed the high-fat diet for three weeks till the occurrence of hyperlipidemia. GII: was fed the high-fat diet for three weeks (hyperlipidemic) then sacrificed. GIII: hyperlipidemic rats were then treated orally with (S; $1.5 \mathrm{mg} / \mathrm{rat} /$ /day) for 4 weeks. GIV: hyperlipidemic rats were then treated orally with (LC; $20 \mathrm{mg} / \mathrm{rat} /$ day) for 4 weeks. GV: hyperlipidemic rats were then treated with (S) and (LC) at the same time. Samples were taken and processed for light and electron microscopic studies.
\end{abstract}

Results: Application of (S) induced multiple changes of muscles as loss of transverse striations, splitting of myofibrils, and presence of central nuclei. Treatment with (LC) causes improvement of these changes.

Conclusion: Application of (LC) improved the degenerative changes of muscle obtained by administration of (S).

Received: 09 October 2019, Accepted: 11 November 2019

Key Words: Electron microscope; hyperlipidemia; L- Carnitine; simvastatin; skeletal muscles.

Corresponding Author: Fatma Alzahraa N. Al-Shahed, MD, Department of Histology and Cell Biology, Faculty of Medicine, Al-Azhar University, Cairo, Egypt, Tel.: +20 1001035262, E-mail: jomana_ali95@yahoo.com

ISSN: 1110-0559, Vol. 43, No. 1

\section{INTRODUCTION}

Hyperlipidemia is a metabolic disorder that involves abnormally increased levels of lipids [such as cholesterol] and lipid-protein in the blood. It is one of the focal hazards of atherosclerosis, cerebral stroke, coronary heart disease, myocardial infarction and renal failure ${ }^{[1]}$. An effective way to decrease the associated morbidity and mortality is to treat the high blood cholesterol level with changes in the lifestyle and if that is not sufficient enough, with medications $^{[2]}$.

Simvastatin is one of the worldwide frequently prescribed drugs because of its excellent hypolipidemic performance and relatively low price as a generic drug. They are used in clinical practice for hypercholesterolemia treatment, for primary and secondary decreasing incidence of cardiovascular disorders and stroke, due to their capability to lowers up to $55 \%$ of low-density lipoprotein in plasma (LDL) $)^{[3,4]}$. Statins are one of the world's most prescribed drugs ${ }^{[5]}$. In addition, statins have multiple effects that assist in improving endothelial function, stabilize plaques and decrease oxidative stress and inflammation ${ }^{[6]}$. Simvastatin acts by many mechanisms; it inhibits $\beta$-Hydroxy $\beta$-methylglutaryl-CoA (HMG-COA) reductase, reduces production of cholesterol, and increases LDL receptor sensitivity in the liver and Highdensity lipoprotein (HDL) level, meanwhile decreases triglycerides (TG) level in blood circulation ${ }^{[7]}$. However, statins are associated with some side effects although it is known to have a good safety record; the most common of which are related to muscle ${ }^{[8-10]}$.

Simvastatin is known for its higher association with myopathy than other statins ${ }^{[1]}$ and this adverse effect was pharmacokinetics related ${ }^{[12]}$. The pharmacokinetics of simvastatin is mainly determined by its disposition [i.e., distribution and metabolism] rather than its absorption ${ }^{[13]}$. Simvastatin, as a pro-drug, undergoes extensive metabolism (including first-pass metabolism) to the extent that its absolute bioavailability is less than 
$5 \%{ }^{[14]}$. Distribution (e.g., influx and efflux across the liver cell membrane) of simvastatin is mainly through passive diffusion due to its lipophilic property ${ }^{[15]}$.

The clinical evidence of statin-associated muscle disorders ranges from benign myalgia to severe myopathy, up to the life-threatening rhabdomyolysis. Advanced age patients, suffering from senile muscle atrophy and loss of performance is an increased risk of statin-induced muscle disorder ${ }^{[16]}$. Although the pathological mechanism of the myopathy associated with a statin was studied in detail and many theories existed, there is still no real consent ${ }^{[17]}$. The currently dominant ideas include genetic predisposition, mitochondrial dysfunction, lack of prenylated proteins and coenzyme Q10, abnormal cell membrane function and altered calcium homeostasis ${ }^{[18]}$. Statin-tempted myotoxicity happens mostly as a result of mitochondrial injury and oxidative $\operatorname{stress}^{[19,20]}$.

Statins toxicity is thought mostly to be caused by mitochondrial oxidative strain and lowering of mitochondrial respiration. L-Carnitine (LC), has antioxidant properties and can reduce formation of superoxide radicals ${ }^{[21]}$. LC is mostly concentrated in skeletal muscles [about $95 \%$ of all body stores], and its convenience is important for the physiological processes of $i^{t^{22]}}$. The risk of myopathy persuaded by statin therapy seems to be dose-dependent and independent of decrease in LDL cholesterol ${ }^{[23]}$.

The mechanism of myopathy caused by statins is not completely clear. A dose-related and pro-apoptotic effect, mitochondrial direct-effects, drug interactions and genetic features, or mixtures may be elaborated. Recently, a rare immune-mediated myopathy created by statin use has been designated ${ }^{[24]}$. Mitochondria play a central role in cellular energy provision and metabolism through the tri-carboxylic acid cycle, beta-oxidation of fatty acids, and production of reactive oxygen species, oxidative phosphorylation, cell division, and apoptosis. Mitochondrial dysfunction is believed to be the main cause of statin-induced myopathy ${ }^{[25]}$.

L-carnitine (LC), an endogenous mitochondrial membrane compound, has a role in enabling the conveyance of long-chain fatty acids into mitochondrion for ingoing $\beta$-oxidation trail. It may be formed by amino acids, methionine and lysine or taken by food supply ${ }^{[26]}$. Many studies suggested that LC lowers oxidative stress and guards mitochondria from fatty acid stress and apoptosis initiation through the stoppage of mitochondrial swelling and Cytochrome-c release ${ }^{[27]}$. Carnitine plays a critical role in energizing mitochondrial membrane potential, cardiolipin component and oxygen consumption in mitochondrial dysfunction related to age ${ }^{[28]}$. Additionally, LC effectively augmented the endogenous antioxidant protection capacity, modified bioenergetics supported by mitochondrial and attenuates age-related changes ${ }^{[29]}$. Recent signs propose that carnitine intake may act as radical scavenger, thus helping in protection from statinmade oxidative muscle damage ${ }^{[30,31]}$. The present study was designed to study to evaluate the effect of simvastatin drug on the histological structure of skeletal muscle fibers of senile male albino rats and the possible protective effect of LC.

\section{MATERIALS AND METHODS}

Material

\section{Drugs}

a. Simvastatin commercially known as (Simvacor $40 \mathrm{mg}$ tablets), purchased from (Sigma company for pharmaceutical and chemical industries). The daily single oral dose was $(7.2 \mathrm{mg} / \mathrm{kg}$ body weight /day) (1.5 mg /rat/day), dissolved in distilled water and given orally once by a gastric tube for 4 weeks. The dose was calculated in accordance with $^{[32]}$. This dose was equivalent to the human high therapeutic dose of $80 \mathrm{mg}$ once daily. It was selected according to ${ }^{[33,34]}$ who recommend this dose for greater lipid goal achievement and more effective cardiovascular prevention.

b. L-Carnitine commercially known as (Carnitol $500 \mathrm{mg}$ capsules); it was purchased from Global Napi Company for pharmaceutical and chemical industries. The daily single oral dose was $(100 \mathrm{mg} /$ $\mathrm{kg}$ bodyweight/day $) \sim(20 \mathrm{mg} / \mathrm{rat} /$ day $)$ dissolved in distilled water and given orally by gastric tube for 4 weeks. It is the recommended dose for rats ${ }^{[35]}$.

\section{Animals}

The present study was performed on thirty senile male albino rats, their average weight was 200-250 gm. and their ages were about 18-24 months old. They were handled according to the guidelines and ethics of the animal protocol of faculty of Medicine Al-Azhar University, Cairo, Egypt. They were kept in well-ventilated stainless-steel cages, at normal room temperature, and 12 hours light/dark cycle with strict care and hygienic measures. All rats were freely provided with water and rat chow. They were left for one week before the starting of the experiment for acclimatization.

\section{Methods}

\section{Induction of experimental hyperlipidemia}

After one week of acclimatization Animals were divided into five groups, six rats each. The first served as control group which fed on standard rodent chow. All other groups had free access to high fat diet (Vanaspati ghee and coconut oil) in a ratio of 3: 2 respectively in addition to normal diet for 3 weeks $^{[36,37]}$.

\section{Animal groups}

a. Control group (G I): Included 6 rats, fed on standard rodent chow all through the experiment.

b. Hyperlipidemic group (G II): Included 6 rats, were daily fed on high fat diet for 3 weeks only to induce hyperlipidemia, and then sacrificed. 
c. Hyperlipidemic, Simvastatin treated group (G III): Included 6 rats, were daily fed on high fat diet for 3 weeks, and then treated with simvastatin for 4 weeks.

d. Hyperlipidemic, LC treated group (G IV): Included 6 rats, were daily fed on high fat diet for 3 weeks, and then treated daily for 4 weeks with LC.

e. Hyperlipidemic, Simvastatin and LC treated group (GV): Included 6 rats, were daily fed on high fat diet for 3 weeks, and then treated for 4 weeks with both Simvastatin and LC at the same time.

\section{Biochemical parameters}

Blood samples of all groups were obtained after 3 weeks and at the termination of the experiment. All the animals were kept for next overnight fasting, $2 \mathrm{ml}$ of blood was collected at the morning from the orbital sinus with the help of a capillary tube by pressing the thumb behind the angle of the jaw resulting in the engorgement of retroorbital plexus ${ }^{[38]}$. The blood was centrifuged; serum was collected and the parameters of lipid profile were estimated as the following: 1) $\mathrm{TC}^{[39]}$; 2) $\mathrm{TG}^{[40]}$; 3) $\mathrm{HDL}^{[41]}$; and 4) $\mathrm{LDL}^{[42]}$.

\section{Histological techniques}

(A) Light microscopic techniques: The animals were anaesthetized by ether inhalation, the gastrocnemius muscle of the right leg of each rat was dissected and cut into smaller pieces. The specimens fixed in $10 \%$ formalin, dehydrated in ascending grades of ethyl alcohol, cleared in xylene, impregnated and embedded in pure molten paraffin wax, sectioned on a rotary microtome at $5 \mu \mathrm{m}$ thicknesses and mounted on an albumenized glass slide ${ }^{[43]}$. Sections then stained with the following methods:

- Hematoxylin and Eosin (H\&E) for studying the general structure ${ }^{[4]}$

- Mallory's trichrome stain for staining the collagen fibers $^{[45]}$.

- Periodic acid Schiff's (PAS) technique for detection of glycogen content of skeletal muscle ${ }^{[44]}$.

(B) Electron microscopic technique: The specimens taken from the rats were alive under anesthesia. Longitudinal muscle strips from the gastrocnemius muscle of the left leg from all groups were collected, trimmed into small pieces approximately $0.5 \mathrm{~mm} 3$, immediately fixed by immersion in $5 \%$ glutaraldehyde in $0.1 \mathrm{M}$. sodium cacodylate buffer, $\mathrm{pH} 7.3$ at $0-4 \mathrm{oC}$ for 8 hours ${ }^{[46]}$. Post-fixation was carried out in $1 \%$ osmium tetra-oxide, dehydrated in ascending grades of ethyl alcohol ${ }^{[47]}$ cleared in propylene oxide, embedded in epoxy resin then left for 24 hours in an oven at $400 \mathrm{C}$ for resin polymerization ${ }^{[48]}$. The sections were cut on an LKB ultra-microtome using glass knife into $0.5 \mu \mathrm{m}$ semi-thin sections stained with toluidine blue then ultrathin sections were cut $(80 \mathrm{~nm})$ and picked up on a 200 mesh copper grids ${ }^{[48]}$. Sections were examined and photographed by JEOL 1010 transmission electron microscope (Jeol; Tokyo, Japan).

\section{Morphometric study}

Data were obtained using "Leica Qwin 500 C" image analyzer computer system Ltd. (Cambridge, England) to measure the following parameters:

1. Area percent of collagen fibers in Mallory's trichrome stained sections was done in 10 non overlapping microscopic fields at magnification $\mathrm{x} 400$.

2. Optical density of PAS +ve reaction in PAS stained sections was done in 10 non overlapping fields in each section at magnification $\mathrm{x} 400$.

\section{Statistical analysis}

Data analyzed using statistical package for social science (SPSS) version 21. Results were expressed as mean \pm standard error. Different results were analyzed statistically using: ANOVA (Analysis of Variance): for comparison of quantitative data of more than two groups. The probability $(P$-value $)$ of $<0.05$ was considered statistically significant.

\section{RESULTS}

\section{Biochemical results}

In the current study the successful induction of hyperlipidemia was detected by the significant increase of serum cholesterol, LDL and triglyceride in rats.

The mean values of serum cholesterol, TG, LDL and HDL $(\mathrm{mg} / \mathrm{dl})$ in all rats of experimental groups after induction of hyperlipidemia for 3 weeks and by the end of the experiment were illustrated in (Table 1, Histogram1\&2).

We observed that the levels of serum cholesterol, triglycerides and LDL were significantly increased in all groups in comparison to GI $(p \leq 0.05)$; however, the serum level of HDL was significantly decreased in comparison to GI $(p \geq 0.05)$.

Comparing the lipid profile by the termination of the experiment discovered that the levels of serum cholesterol, triglycerides and LDL were significantly decreased in GIII, GIV and GV in comparison to GII; however, the serum level of HDL was increased significantly if compared to GII.

\section{Histological results}

\section{Light microscopic results}

Examination of H\&E stained longitudinal section (LS) in the gastrocnemius muscle of the control group (G I) showed the structure of the skeletal muscle. The muscle fibers appeared parallel, non-branching and cylindrical in shape. They have acidophilic sarcoplasm and clear transverse striations of alternating dark and light bands. The nuclei were multiple elongated, peripheral just beneath the sarcolemma (Figure 1a). Examination of (GII) revealed segmental degeneration of the muscle fibers, 
a part of the fibers showed loss of striations in the affected regions. Nuclei were obviously seen shifted to the central part of fibers in some areas (Figure 1b). Some muscle fibers appeared with wavy sarcolemma, wavy myofibrils having in-between areas of hemorrhage with splitting of some muscle fibers (Figure 1c).

Examination of (GIII) showed more muscular degenerative changes in the form of complete loss of transverse striations, more splitting of myofibrils, and presence of pyknotic peripheral nuclei (Figure 1d). Degeneration extended to massive destruction with dramatic loss of muscle architecture, loss of transverse striations, central small dark nuclei and some reached to the extent of complete destruction of the muscle fibers with mononuclear cell infiltration (Fiure 1e)

Examination of (GIV) showed improvement in the structure of the skeletal muscle; Restored transverse striations in many areas with aggregation of central vesicular nuclei, however splitting of some fibers was still observed (Figure 1f)

Examination of $(\mathrm{GV})$ showed multiple histological changes; some fibers appeared striated with peripheral nuclei, others showed patchy loss of striation and splitting; however, other muscle fibers appeared intact (Figure 1g).

Examination of sections stained with Mallory's trichrome of the control group (GI) revealed the presence of bundles of muscle fibers (fascicles) separated by thin connective tissue (perimysium). The fibers were surrounded by delicate CT which enclose fibers and connect them together (endomysium). Few blue stained collagen fibers were seen in-between the muscle fibers and around the blood vessels (Figure 2a).

In hyperlipidemic rats, (GII) the gastrocnemious muscle showed mild to moderate increase in the collagen fibers inbetween the muscle fibers (Figure 2b). Marked increase in the collagen fibers was obviously seen in (GIII) in-between the muscle fibers as well as filling the wide degenerated areas (Figure 2c). Nearly normal appearance could be seen in rats treated with L-carnitine, (GIV).

The blue collagen fibers were few in-between the muscle fibers as well as around the blood vessels, as compared with Group II (Figure 2d). GV showed mild to moderate decrease in the collagen fibers in-between the muscle fibers as well as around the blood vessels as compared with Group III (Figure 2e).

Examination of sections stained with PAS of the control group (GI) declared the normal distribution of PAS + ve reaction in the skeletal muscle fibers; there were noticed two types of muscle fibers. Strong PAS +ve reaction appeared in some fibers while others appeared faint both appeared with obvious normal transverse striations (Figure 3a)

In (GII) moderate decrease in PAS + ve reaction was seen, however patchy areas appear with weak reaction in the skeletal muscle (Figure 3b). Examination of (G III) showed marked decrease in PAS +ve reaction in the skeletal muscle however, marked increase of PAS + ve reaction obviously seen at the margins of the muscle (L.S and T.S) (Figure 3c).

Marked restoration of PAS +ve reaction could be detected in the skeletal muscle of rats of GIV, near to normal (Figure 3d). In Group V some muscle fibers appeared with marked increase in PAS +ve reaction while others showed faint reaction (Figure 3e).

\section{Electron microscopic results}

Electron microscopic examination of sections from GI showed that the myofibrils were seen filled the sarcoplasm settled parallel to the long alliance of the myofibers. Regular architecture of alternating light (I) and dark (A) bands was noticed. An electron-lucent narrow region, the $\mathrm{H}$ band, was seen at the center of the $\mathrm{A}$ band with a dark electron-dense line ( $\mathrm{M}$ line) within it. At the middle of the light band Z-line was seen. Sarcomere extends between two consecutive Z-lines. Flat heterochromatic nuclei were present beneath the sarcolemma (Figure 4).

In GII there is Irregularities in myofibrils, congested blood capillaried with RBCs inside its lumen ,presence of fibroblast nucleus and increased collagen fibers is also noticed (Figure 5)

In GIII there was focal degeneration of myofibrils, deviation of Z-lines, together with corrugated nuclear membrane. There is also increased collagen fibers, appearance of autophagic vacuoles and accumulation of glycogen granules (Figure 6).

In Group IV an improvement in the arrangement of the myofibrils with light and dark bands was noted (Figure 7).

In Group V some myofibrils appeared normal having in-between well detected disorganized areas, degenerated parts with loss of $\mathrm{Z}$ line also observed (Figure 8).

\section{Morphometric results}

\section{Collagen area percentage in all the experimental groups}

A significant difference was detected in the percentage of collagen fibers of the gastrocnemius muscle in the different groups, the highest mean value of collagen area\% was observed in GIII and GII, while the least mean value of collagen area $\%$ was observed in GI, GIV and GV respectively. The results were statistically significant $(p \leq 0.05)$, (Table 2, Histogram 3 ).

\section{Changes in the optical density of $P A S$ reaction in all the experimental groups}

A significant difference was present in the optical density of PAS + ve reaction in the skeletal muscle fibers in the different groups when compared to the control group especially in GIII as $(p \leq 0.05)$. The least mean value was observed in GIII, while the highest mean value was observed in GI and GIV. The mean value in GII and GV was reduced respectively being marked in GII, (Table 3, Histogram 4). 
Table1: Comparison of the lipid profile after 3 weeks and at the end of the experiment among the different experimental groups

\begin{tabular}{|c|c|c|c|c|c|}
\hline \multirow{8}{*}{$\begin{array}{l}\text { Lipid profile } \\
(\mathrm{mg} / \mathrm{dl}) \text { after } \\
3 \text { weeks }\end{array}$} & & $\begin{array}{l}\text { Serum cholesterol } \\
(\mathrm{mg} / \mathrm{dl})\end{array}$ & $\begin{array}{c}\text { Serum triglyceride } \\
(\mathrm{mg} / \mathrm{dl})\end{array}$ & $\underset{(\mathrm{mg} / \mathrm{dl})}{\operatorname{Serum} L D L}$ & $\underset{(\mathrm{mg} / \mathrm{dl})}{\operatorname{Serum} H D L}$ \\
\hline & & Mean \pm SD & Mean \pm SD & Mean \pm SD & Mean \pm SD \\
\hline & Group I $(\mathrm{N}=6)$ & $95.6 \pm 3.8$ & $79.7 \pm 7.4$ & $64 \pm 6.97$ & $29.6 \pm 4.83$ \\
\hline & Group II $(\mathrm{N}=6)$ & $143.67 \pm 2.5^{*}$ & $139.8 \pm 9.5^{*}$ & $123.8 \pm 10.1^{*}$ & $28.8 \pm 4.43$ \\
\hline & Group III $(\mathrm{N}=6)$ & $139.8 \pm 6.72^{*}$ & $143.5 \pm 4.5^{*}$ & $128 \pm 8.42^{*}$ & $26.6 \pm 3.72$ \\
\hline & Group IV $(\mathrm{N}=6)$ & $141.3 \pm 4^{*}$ & $140.4 \pm 4^{*}$ & $123.9 \pm 5.99^{*}$ & $24.4 \pm 2.5$ \\
\hline & Group V $(\mathrm{N}=6)$ & $143.5 \pm 4.2^{*}$ & $139.3 \pm 7.2^{*}$ & $127.3 \pm 4.92^{*}$ & $26.7 \pm 3.46$ \\
\hline & Pvalue & $0.000^{*}$ & $0.000^{*}$ & $0.000^{*}$ & 0.269 (NS) \\
\hline \multirow{8}{*}{$\begin{array}{c}\text { Final lipid } \\
\text { profile }(\mathrm{mg} / \mathrm{dl})\end{array}$} & & $\begin{array}{l}\text { Serum cholesterol } \\
(\mathrm{mg} / \mathrm{dl})\end{array}$ & $\begin{array}{c}\text { Serum triglyceride } \\
(\mathrm{mg} / \mathrm{dl})\end{array}$ & $\underset{(\mathrm{mg} / \mathrm{dl})}{\operatorname{Serum} L D L}$ & $\underset{(\mathrm{mg} / \mathrm{dl})}{\operatorname{Serum} H D L}$ \\
\hline & & Mean \pm SD & Mean \pm SD & Mean \pm SD & Mean \pm SD \\
\hline & Group I $(\mathrm{N}=6)$ & $95.6 \pm 3.8$ & $79.7 \pm 7.4$ & $64 \pm 6.97$ & $29.6 \pm 4.83$ \\
\hline & Group II $(\mathrm{N}=6)$ & $143.67 \pm 2.5$ & $139.8 \pm 9.5$ & $123.8 \pm 10.1$ & $28.8 \pm 4.43$ \\
\hline & Group III $(\mathrm{N}=6)$ & $109.5 \pm 6.67^{*}$ & $118.4 \pm 4.4^{*}$ & $89.4 \pm 9.3^{*}$ & $36 \pm 2.28^{*}$ \\
\hline & Group IV $(\mathrm{N}=6)$ & $104.66 \pm 6.07^{*}$ & $111.6 \pm 6.4^{*}$ & $99.6 \pm 6.11^{*}$ & $33 \pm 1.4^{*}$ \\
\hline & Group V $(\mathrm{N}=6)$ & $104.5 \pm 5.2^{*}$ & $104.4 \pm 9.2^{*}$ & $87.4 \pm 3.5^{*}$ & $35.2 \pm 2.4^{*}$ \\
\hline & Pvalue & $0.000^{*}$ & $0.000^{*}$ & $0.000^{*}$ & $0.000^{*}$ \\
\hline
\end{tabular}

$*$ p-value $\leq 0.05$ was considered as statistically significant.

SD: standard deviation NS: non-significant

$\mathrm{N}$ : number of rats in each group

Table 2: Changes in the percentage of collagen fibers among the different experimental groups

\begin{tabular}{lccccc}
\hline & $\mathrm{N}$ & Mean & S.D. & S.E & Pvalue \\
\hline Group I & 10 & 1.412 & 0.102 & 0.032 & \\
Group II & 10 & $6.571^{*}$ & 2.001 & 0.633 & \\
Group III & 10 & $16.520^{*}$ & 2.432 & 0.769 & $\leq 0.05$ \\
Group IV & 10 & $2.610^{*}$ & 0.383 & 0.121 & \\
Group V & 10 & $4.498^{*}$ & 1.072 & 0.383 & \\
\hline
\end{tabular}

*statistically significant $P$ value $\leq 0.05$

$\mathrm{N}$ : number of rats in every group. SD: standard deviation. SE: standard error

Table 3: Changes in the optical density of PAS reaction among the different experimental groups

\begin{tabular}{lccccc}
\hline & $\mathrm{N}$ & Mean & S.D. & S.E & P value \\
\hline Group I & 10 & 1.087 & 0.214 & 0.068 & \\
Group II & 10 & $0.400^{*}$ & 0.213 & 0.067 & \\
Group III & 10 & $0.229^{*}$ & 0.096 & 0.030 & $\leq 0.05$ \\
Group IV & 10 & $0.910^{*}$ & 0.080 & 0.025 & \\
Group V & 10 & $0.662^{*}$ & 0.231 & 0.073 & \\
\hline
\end{tabular}

*statistically significant $\mathrm{P}$ value $\leq 0.05$

$\mathrm{N}$ : number of rats in every group. SD: standard deviation. SE: standard error.

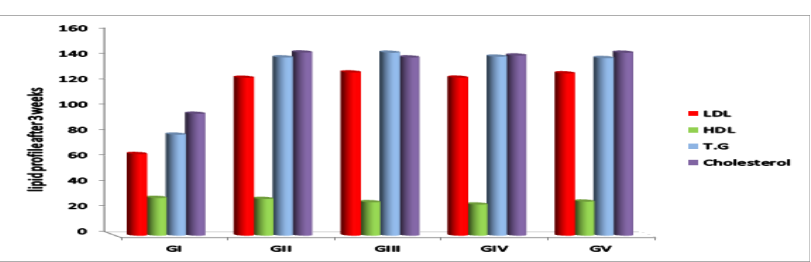

Histogram 1: Showing comparison of the lipid profile after 3 weeks among the different experimental groups

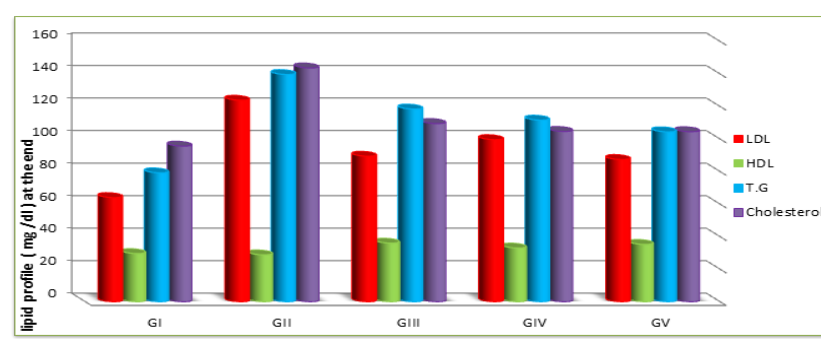

Histogram 2: Showing comparison of the lipid profile at the end of the experiment among the different experimental groups

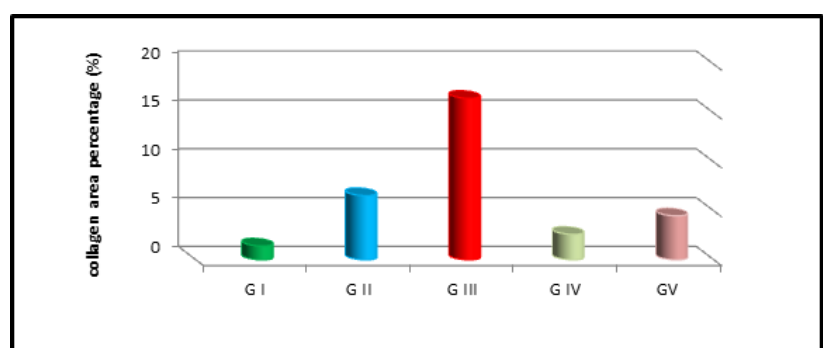

Histogram 3: Changes in the percentage of collagen fibers among the different experimental groups

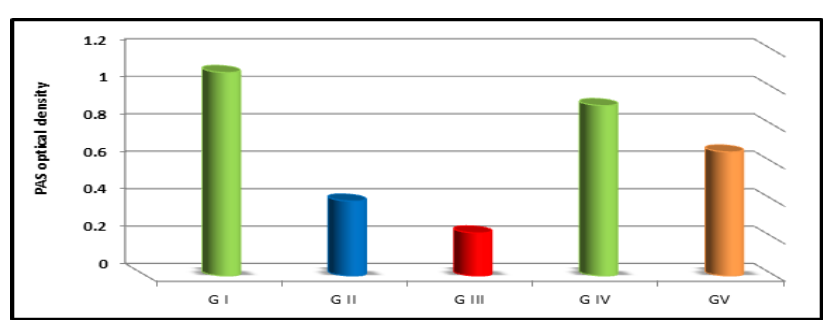

Histogram 4: Showing changes in the optical density of PAS reaction among the different experimental groups 

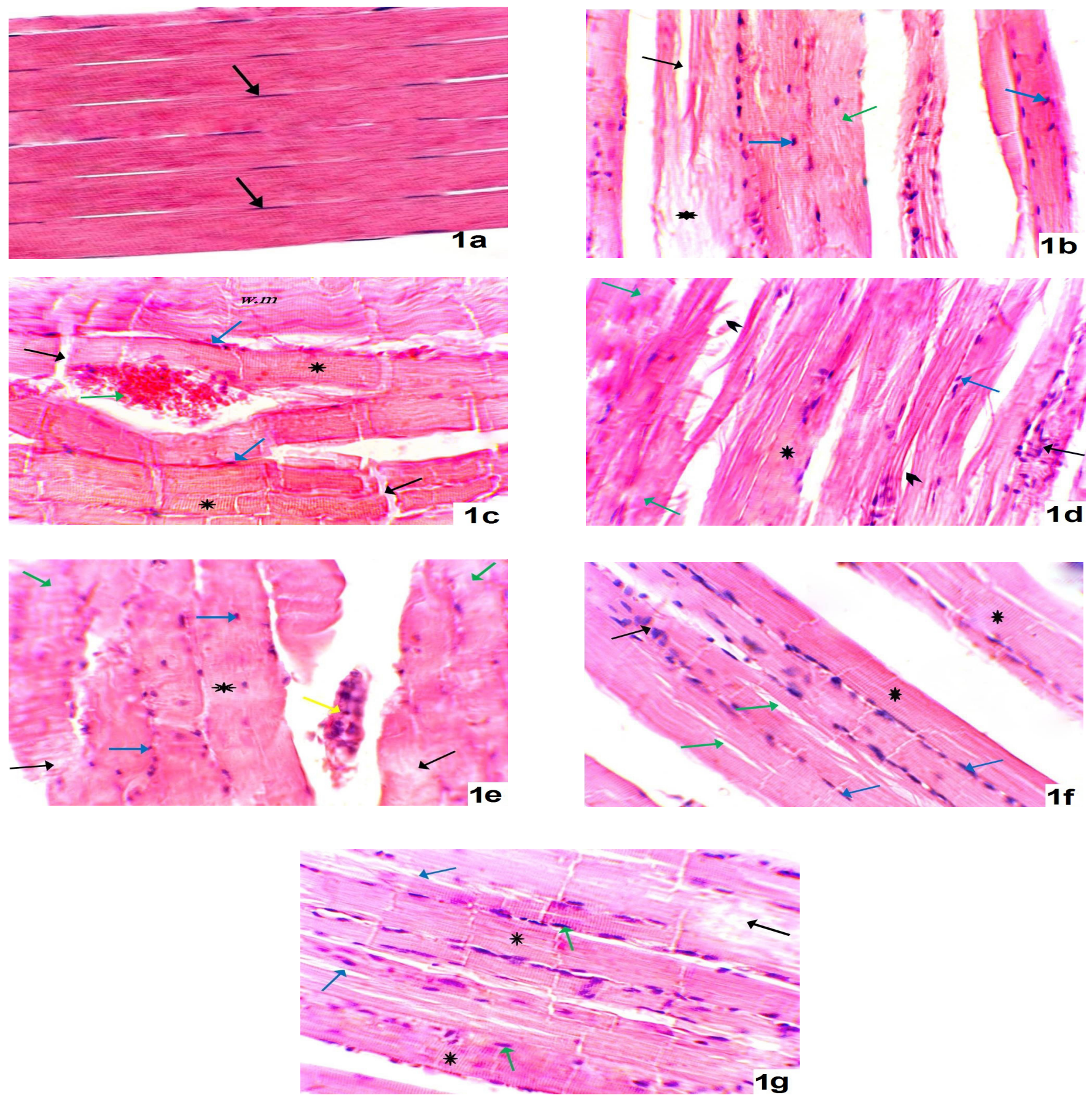

Fig. 1: (GI) (a) Non-branching, cylindrical and parallel muscle fibers. Multiple peripheral nuclei beneath the sarcolemma (arrows). Deep acidophilic sarcoplasm with clear transverse striations.(G2) (b): regular striations (green arrow), central nuclei (blue arrows), segmental degeneration (asterisk), splitting, loss of striations and loss of nuclei (black arrow), (c) wavy sarcolemma and myofibril (w.m), Splitting (black arrow) regular striations (asterisks), pyknotic nuclei (blue arrow) and hemorrhage (green arrow). (G3) (d): Loss of architecture of some fibers (green arrow), splitting (arrow heads) pyknotic nuclei (blue arrow), faint transverse striations (asterisk) \& mononuclear cell infiltration is seen (black arrow). (e) loss of architecture, homogenous deep acidophilic sarcoplasm (green arrows), Pale degenerated areas (black arrow), loss of striations although, faint striations (asterisk), small dark peripheral \& central nuclei (blue arrow) \& area of necrosis with mononuclear cell infiltration (yellow arrow). (G4) (f) restored transverse striations (asterisk) with peripheral nuclei (blue arrows) aggregation of nuclei in the center (black arrow) and Splitting of muscle fibers (green arrows). (G5) (g) restored striations(asterisk), peripherally located nuclei (green arrows), splitting (blue arrows) and segmental degeneration (black arrow).(H\& E. x 400) 

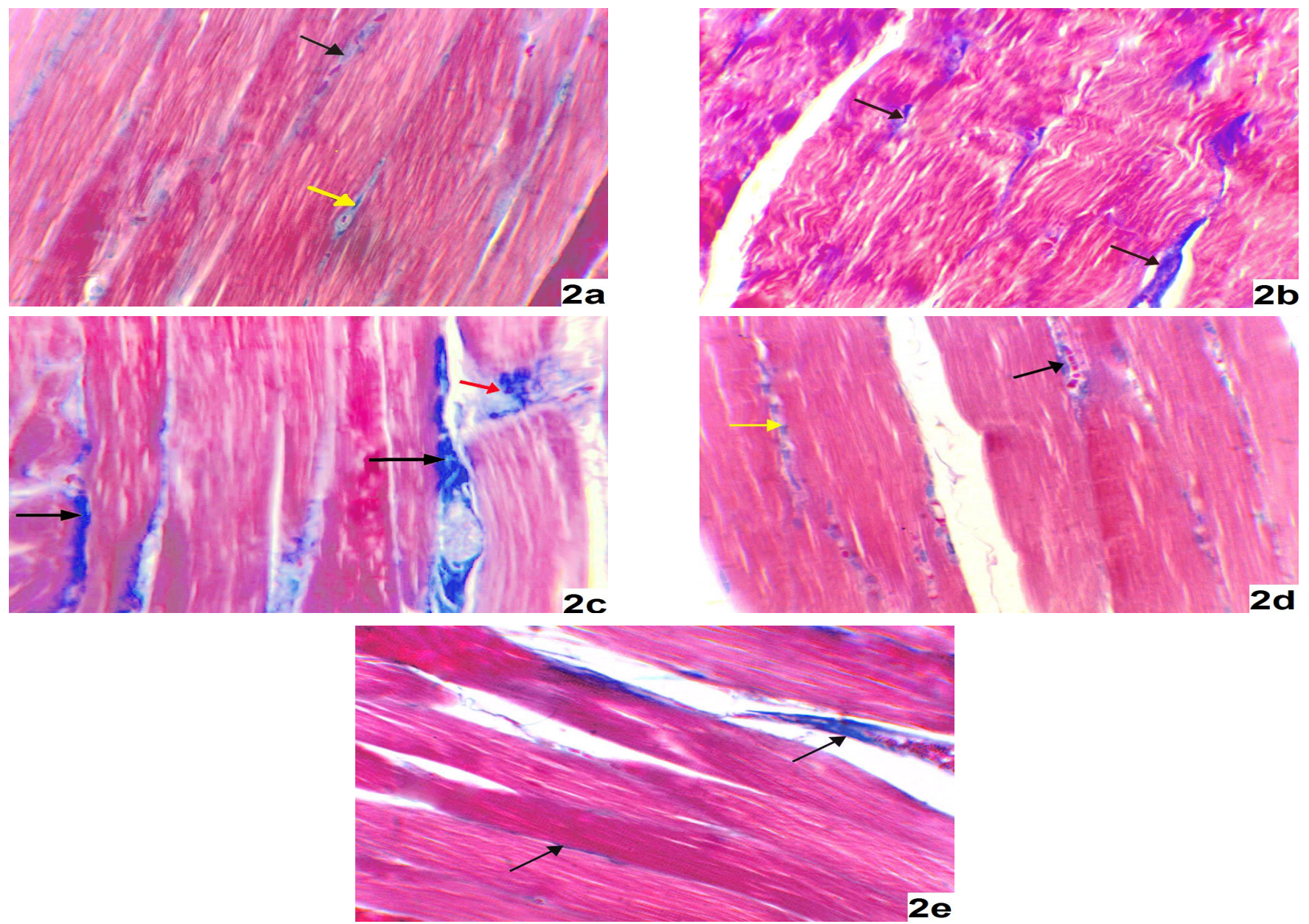

Fig. 2: (GI) (a) few collagen fibers in between the muscle fibers (black arrow) and around the blood vessels (yellow arrow). (GII) (b) moderate increase in the collagen fibers (black arrows). (GIII) (C) marked increase in the collagen fibers (black arrows). (GIV) (D): few collagen fibers in-between the muscle fibers (yellow arrow) and around the blood vessels (black arrows). (GV) (e) mild to moderate decrease in collagen fibers in comparison to GIII (black arrow) (Mallory's trichrome stain x 400)
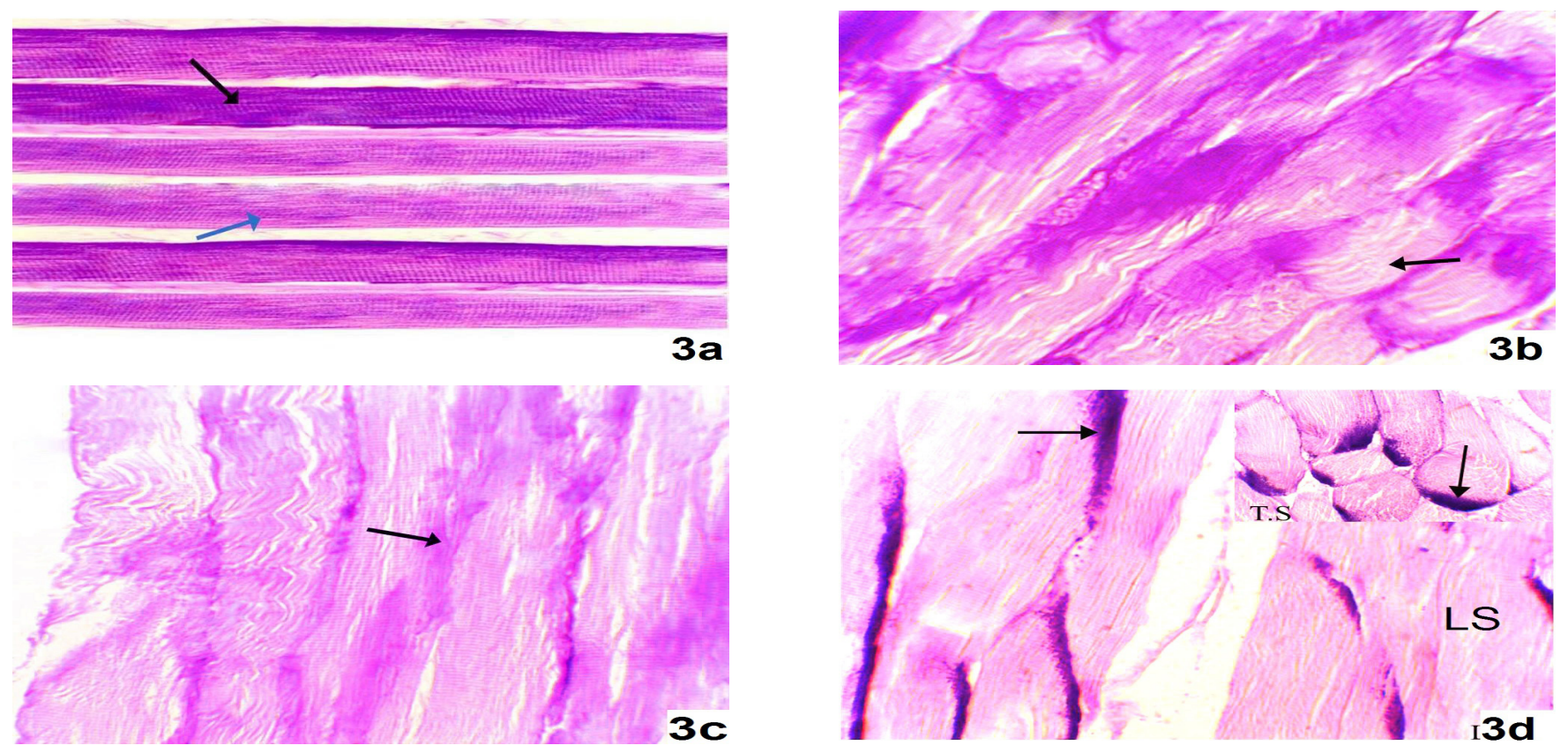


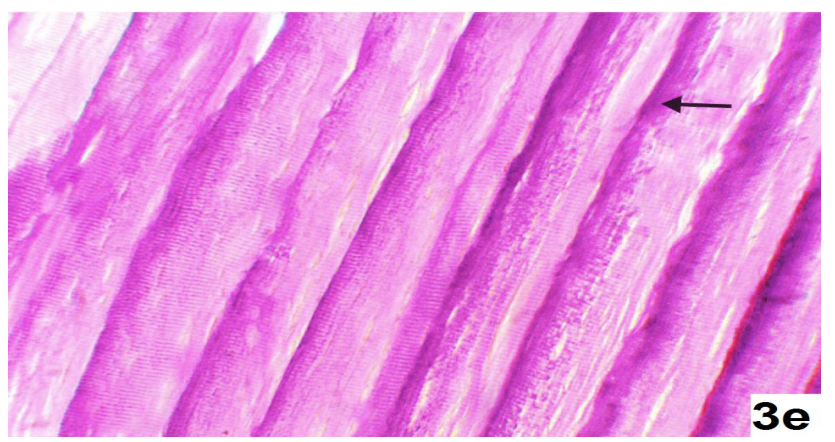

Fig. 3: (GI) (a) Some muscle fibers showed intense PAS +ve reaction (black arrow), while others showed faint PAS +ve reaction (blue arrow) (GII) (b) moderate decrease in PAS reaction and patchy areas of weak reaction (black arrow). (GIII) (c) marked decrease in PAS reaction, however intense PAS reaction is seen at the periphery of the muscle fibers (black arrows). (G IV) (d) marked decrease in PAS reaction, however intense PAS reaction is seen at the periphery of the muscle fibers (L.S\&T.S) (black arrows). (GV) (E) moderate increase in PAS reaction however intense PAS reaction is seen at the periphery of the muscle fibers (blackarrow). (PAS X 400)

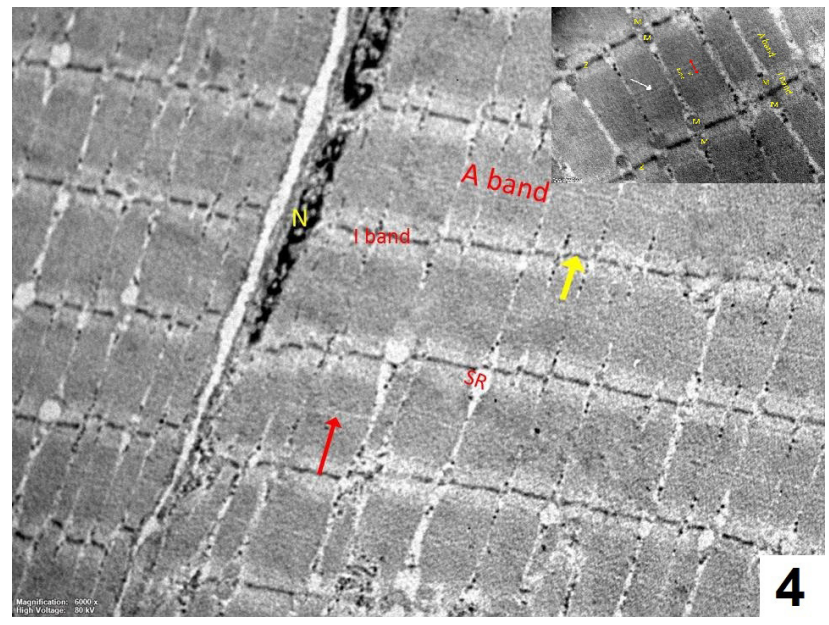

Fig. 4: An electron micrograph of (GI) showing: parallel arrangement of the myofibrils with alternating light (I) and dark (A) bands. $\mathrm{Z}$ line (yellow arrow) is seen bisecting the light band. Elongated heterochromatic nuclei $(\mathrm{N})$ are seen under the sarcolemma. Sarcoplasmic reticulum is also seen (SR). Inset showing higher magnification. (Uranyl acetate and Lead citrate X 6000, 20000)

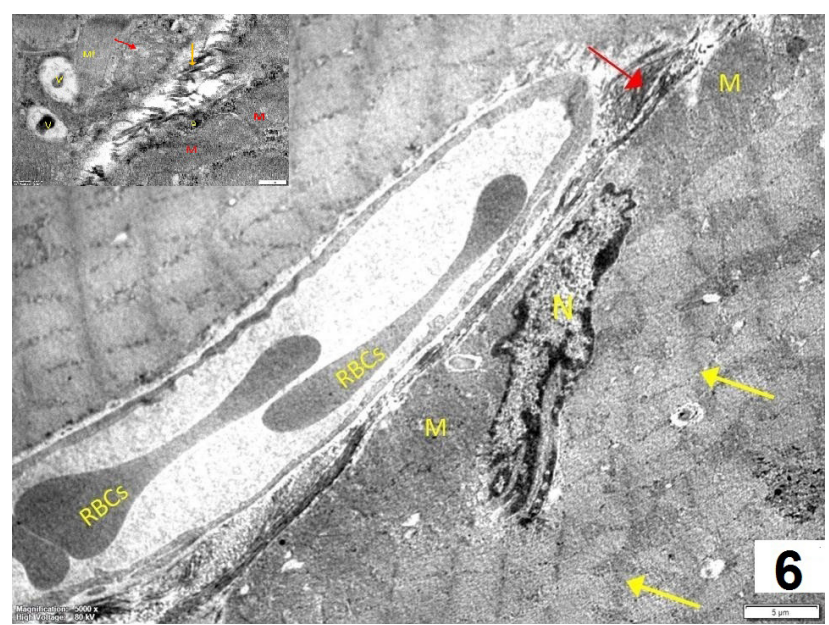

Fig. 6: An electron micrograph of (GIII) showing irregularities of $\mathrm{Z}$ lines \& distorted sarcomere (yellow arrow), degenerated parts of myofibrils \& irregular nuclear membrane. Inset showing accumulation of collagen fibers (red arrow), discontinuity of myofibril (MF) with accumulation of autophagic vacuoles (V). (Uranyl acetate and Lead citrate X 5000, 40000)

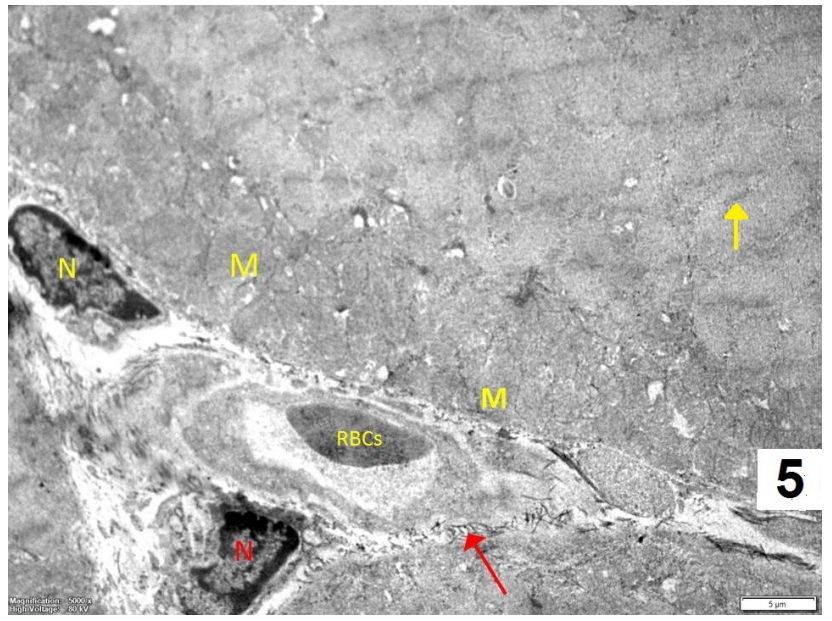

Fig. 5: An electron micrograph of (GII) showing: distorted sarcomere with irregular Z-line, Congested blood capillary with RBCs inside it, accumulation of collagen fibers (red arrow) and appearance of fibroblast nucleus(N). (Uranyl acetate and Lead citrate $\mathrm{x}$ 5000)

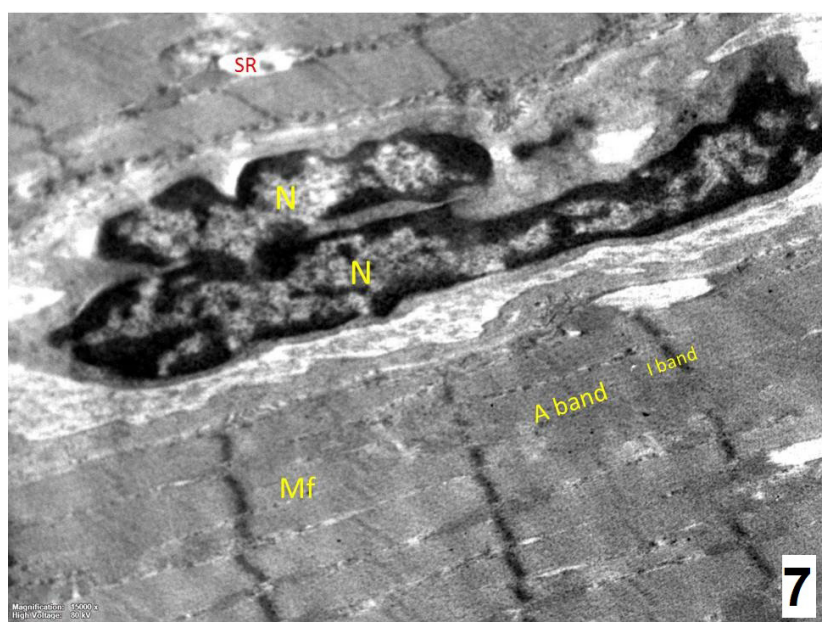

Fig. 7: An electron micrograph of (GIV) showing normal parallel arrangement of myofibril (Mf), and nuclei of fibroblast $\mathrm{N}$. (Uranyl acetate and Lead citrate x 15000) 


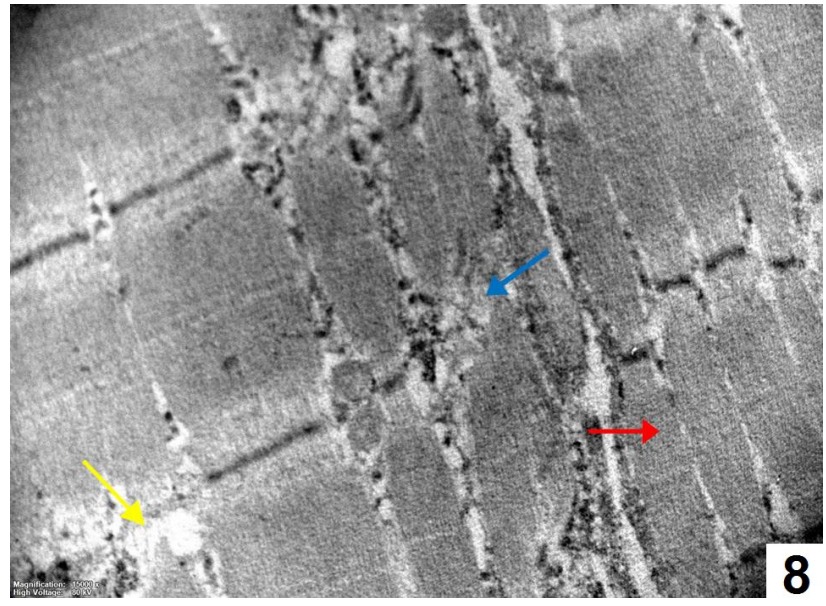

Fig. 8: An electron micrograph of (GV) showing some myofibril appeared disorganized (blue arrow), degenerated parts of myofibrils with loss of $\mathrm{Z}$ lines (yellow arrow) while other myofibrils appear normal (red arrow). (Uranyl acetate and Lead citrate $\mathrm{x} 15000)$

\section{DISCUSSION}

This study was performed on senile male rats because myopathy is higher in aged than in adult subjects ${ }^{[10,49]}$. Thus, muscular manifestations accompanied with statin treatment may lower their use and may be linked with termination of a needed therapy ${ }^{[50]}$. The motive of the high risk of myopathy in the old age is not recognized but the deterioration of muscle function associated with age and diminishing of regenerating capability with metabolic insinuations may play an important role ${ }^{[51]}$.

At first; induction of hyperlipidemia in rats by high fat diet for 3 weeks, followed by administering simvastatin. It was reported that $80 \mathrm{mg} / \mathrm{kg} /$ day of simvastatin is the maximum tolerated dose that causes wide spread muscle degeneration in rats and thus provides a relevant model for myopathy ${ }^{[52]}$.

Selection of gastrocnemius muscle in this study as most of its fibers are formed of type II white fibers ${ }^{[53]}$. It has been reported that statins affects fast type II muscle fibers and causes necrotic changes in them ${ }^{[54]}$. Degenerated muscle can grossly seem either pale or dark. Histologically, degenerated myofibers will exhibit a variation of microscopic changes, such as swollen cell, hypereosinophilia, vacuolization, loss of striation, fragmentation, and rupture of fibers ${ }^{[55]}$.

In the current study, light microscopic examination of $\mathrm{H} \& \mathrm{E}$ stained sections in (G II) revealed evident degeneration of muscle fibers which is noted to be segmental with evident loss of striations in the affected regions. Nuclei were shifted to central part of fibers in some areas, some muscle fibers showed wavy appearance of sarcolemma and wavy myofibrils, areas of hemorrhage and splitting of some muscle fibers. These findings were in agreement with Abdou et al., ${ }^{[56]}$, who reported that large areas of degenerating muscle fibers were pale stained with evident loss of transverse striations, and wide interfascicular spaces were shown in hyperlipidemic effect of diazinon - treated rats.
That was also consistent with El Rabey et al., ${ }^{[57]}$ who reported that the cardiac muscle showed some sorts of hemorrhages and wavy appearance of myofibres, as well as the sarcoplasm of some fibers was characterized by granular appearance, large areas of degenerated muscle fibers with evident loss of transverse striations and wide inter-fascicular spaces in hyperlipidemic group compared to the control group.

These findings were in agreement with Haschek et al. ${ }^{[58]}$ who reported that degeneration often only affects a segment or several segments of the fiber, as opposed to the entire myofiber due to the long length of muscle fibers.

Several studies attributed these changes to excessive production of reactive oxygen species (ROS), results in alteration in the balance between ROS and endogenous antioxidants and creates oxidative stress which is implicated in many pathological conditions ${ }^{[59]}$.

In the current study, Mallory's trichrome stained section of (G II) showed increased collagen fibers inbetween skeletal muscle fibers. These findings were in accordance with Novitskiy et al.,$^{[60]}$ who mentioned that hypercholesterolemia was considered a risk factor for hepatic fibrosis. Studies found that oxidation products such as lipid peroxidation products can stimulate $\alpha$-collagen expression and collagen synthesis ${ }^{[61,62]}$.

PAS stained sections in (GII) showed moderate decrease in PAS reaction. This is in agreement with Alkharfy et al. ${ }^{[63]}$ who reported that 9 weeks of a high fat Westernstyle diet induced defects in skeletal muscle substrate concentrations, including glycogen and lipid contents.

In the present work the ultra-structural analysis in the gastrocnemius muscle of hyperlipidemic group (GII) showed distorted sarcomeres, irregular Z-lines, congested blood vessels increased collagen with appearance of fibroblast. These findings were in agreement with Tomazoni et al., ${ }^{[64]}$ who reported that high fat diet in mice showed great muscle structural abnormalities in HFD group. Furthermore, it appeared weak and was on the border of degenerations. The bands were diminished with loss of connections among myofibrils and these changes due to excessive production of reactive oxygen species and insulin resistance.

In the current study, H\&E stained sections (GIII) showed loss of the normal skeletal muscle architecture, myofibers degeneration, sarcoplasmic fragmentation, inflammatory cellular infiltration, small dark nucleus, myofiber splitting and shift of nucleus to a central position. These results also were similar to the finding of Meregalli et al.. ${ }^{[65]}$, who reported that animals treated with simvastatin exhibited significantly greater morphological and structural skeletal muscle damage.

Westwood et $a l^{[53]}$, reported that after application of elevated doses of statin in rats the necrosis was more widespread categorized by cytoplasmic eosinophilia with loss of cytoplasmic construction and there was 
mononuclear cell and polymorph nuclear cells infiltration, edema and vacuolation with disintegration and loss of cytoplasm.

Meregalli et al., ${ }^{[65]}$ explained why the damaged muscle fibers following injury undergo hyalinization as a result of over contraction precipitated by excessive intracellular $\mathrm{Ca} 2+$. The fibers became necrotic or apoptotic and initiate inflammatory reaction via releasing of mitogenic chemoattractants. It could be suggested that the degenerative changes that affected the muscle fibers might be the stimulus that initiated the inflammatory reaction which explained by Stevnes et al., ${ }^{[66]}$, who suggested that the degenerated fibers release different inflammatory mediators that lead to mononuclear cellular infiltration.

The splitting of the muscle fibers might be due to the insufficient oxygen supply and metabolites exchange to the enlarged and hypertrophied fibers. The central located nuclei have been used also as a marker for muscle fiber damage ${ }^{[6]}$. Centra located nuclei were also reported in cases of muscle fiber regeneration ${ }^{[68]}$.

Abundant collagen fibers appeared (GIII) in-between skeletal muscle fibers. These findings were supported by Fukushima et al., ${ }^{[69]}$ and Li et al., ${ }^{[70]}$ who mentioned that fibrotic process that occurs after muscle injury is promoted by the local release of growth factors such as transforming growth factor- $\beta 1$ (TGF- $\beta 1$ ) and platelet-derived growth factor, which stimulate the cells of the extracellular matrix to produce local collagens and trigger differentiation of myogenic cells to myofibroblasts, which start collagen deposition.

GIII also showed marked decrease of PAS reaction with accumulation of PAS reaction at the margin of muscle fibers. These finding was explained by Al-Doaiss et al., ${ }^{[71]}$ who reported that administration of statins caused depletion of glycogen stores in the hepatocytes. This alteration might be due to the effect of statins on glucose absorption or on the enzymes involved in the process of glycogenesis or/ and glycolysis.

E/M examination of (GIII) showed disorganized sarcomere, irregularities of $\mathrm{Z}$ line, nuclear membrane indentation increased collagen and presence of autophagic vacuoles. These results were in agreement with Obayashi et al., ${ }^{[72]}$ who reported that swollen mitochondria, dilated sarcoplasmic reticulum and accumulation of autophagic vacuoles followed by degenerated myofibrils occur in rats after cervistatin treatment.

Presence of autophagic vacuoles related to alterations to autophagy and/or lysosomal function which are observed in many skeletal muscle disease ${ }^{[73-75]}$ and have also recently been implicated in myofibrillar myopathy ${ }^{[76]}$.

The underlying mechanisms of statin myopathy were explained by Bouitbir et al., ${ }^{[77]}$ who declared that statins have been associated with high oxidative stress in skeletal muscle and this is responsible for transcriptional deactivation of mitochondrial biogenesis together with mitochondrial dysfunction. Bitzur et al., ${ }^{[78]}$ and Stroes et al. ${ }^{[10]}$ suggest that the toxic effect of statins is associated with mitochondrial dysfunction by decreasing energy production and altering muscle protein degradation.

In our study, an improvement was obviously detected in the structure of skeletal muscles of GIV in the form of restored transverse striation of muscle fibers in many areas with aggregated central vesicular nuclei. Splitting of some fibers was also observed. Similar results were reported by Farouk et al., ${ }^{[79]}$ and Artioli et al., ${ }^{[80]}$ who declared that the hypercellularity and central nuclei were prominent features for muscle regeneration. These findings reflected a protective role of $\mathrm{L}$-carnitine.

Murad et al., ${ }^{[81]}$ mentioned that L-Carnitine occupy a vital role in the mitochondrial transport and oxidation of fatty acids. Shehata et al., ${ }^{[82]}$ stated that L-carnitine defend against mitochondrial malfunctions accompanying oxidative strain caused by many factors such as aging, ischemia reperfusion, inflammation, degenerative diseases, carcinogenesis and drug toxicity, in vivo or in vitro. Its mechanism of action was explained by Oyanagi et al., ${ }^{[27]}$ who mentioned that it avoids apoptosis pathway by stimulating mitochondrial respiration and encouraging of cell energy manufacture via $\beta$-oxidation in the mitochondria.

In (GIV) minimal collagen fibers were seen among muscle fibers. These finding are similar to Mazroa et al., ${ }^{[67]}$. There is also restored PAS reaction with focally increased reaction at the periphery of the muscle fibers. These results are reinforced by several studies which reported that L-carnitine halts age-related surges in reactive oxygen species (ROS), lipid peroxidation and DNA strand disruptions in heart, skeletal muscle and brain, concomitant with enhancement in mitochondrial enzyme and respiratory chain activities ${ }^{[83,84]}$.

E/M examination of (GIV) showed normal parallel appearance of myofibrils with dark and light bands which reflected a protective role of L-carnitine. L-Carnitine beside its metabolic role has an antioxidant effect and can directly decrease superoxide radical generation ${ }^{[21]}$.

In the current work, (GV) showed areas of intact muscle fibers and others with remaining histological changes as patchy loss of striation, central nuclei and splitting of some fibers. These results are explained by La Guardia et al., ${ }^{[21]}$ who stated that statins myopathy may occurred 2ry to carnitine levels abnormalities as L-carnitine acts as radical scavenger which prevent oxidative mitochondrial damage and protect muscles. Also Costa et al., ${ }^{[31]}$ mentioned that L-Carnitine guard against simvastatin-induced cell necrosis in prostate cancer- 3 cell line by declining the simvastatin induced mitochondrial hyperproduction of the superoxide anion and preventing oxidative mitochondrial dysfunction.

In (GV) moderate amount of collagen fibers was seen in our study. Tateno et al., ${ }^{[85]}$ said that fibrosis hinders the regenerative ability of skeletal muscle after injury and slow 
their healing process. This leads to incomplete recovery after injury and even formation of disorganized scar tissue that often replaces damaged myofibers and may be a cause of muscular re-injury.

In (GV) E/M examination showed some muscle fibers appear normal while others disorganized. These changes are due to L-Carnitine protective effect against simvastatin-induced cell necrosis through preventing oxidative mitochondrial dysfunction ${ }^{[31]}$.

\section{CONCLUSION}

Application of (LC) improved the degenerative changes of muscle obtained by administration of (S).

\section{CONFLICTS OF INTEREST}

There are no Conflicts of interest.

\section{REFERENCES}

1. $\mathrm{Xu}$ Q, Liu Y, Zhang Q, Ma B, Yang Z, Liu L, et al. Metabolomic analysis of simvastatin and fenofibrate intervention in high-lipid diet-induced hyperlipidemia rats. Acta Pharmacol Sin. (2014) 35(10):1265-73.

2. Bairey Merz CN, Alberts MJ, Balady GJ, Ballantyne CM, Berra K, Black HR, et al. ACCF/AHA/ACP 2009 Competence and Training Statement: A Curriculum on Prevention of Cardiovascular Disease. J Am Coll Cardiol. (2009) 54(14):1336-63.

3. Zambrano T, Hirata RDC, Hirata MH, Cerda Á, Salazar LA. Altered microRNome Profiling in Statin-Induced HepG2 Cells: A Pilot Study Identifying Potential new Biomarkers Involved in Lipid-Lowering Treatment. Cardiovasc Drugs Ther. (2015) 29(6):509-18.

4. Leusink M, Onland-Moret NC, de Bakker PI, de Boer A, Maitland-van der Zee AH. Seventeen years of statin pharmacogenetics: a systematic review. Pharmacogenomics. (2016) (2):163-80.

5. 5. Stone NJ, Robinson JG, Lichtenstein AH, Bairey Merz CN, Blum CB, Eckel RH, et al. 2013 ACC/AHA Guideline on the Treatment of Blood Cholesterol to Reduce Atherosclerotic Cardiovascular Risk in Adults. Circulation. (2014);129(25 suppl 2):S1-45.

6. Alfonsi JE, Hegele RA, Gryn SE. Pharmacogenetics of Lipid-Lowering Agents: Precision or Indecision Medicine? Curr Atheroscler Rep. (2016);18(5):24.

7. Pourmatroud E, Mohammadjafari R, Roozitalab M. Comparison of Metformin and Simvastatin Administration in Women With Polycystic Ovary Syndrome Before Intra-Cytoplasmic Sperm Injection Cycle: A Prospective, Randomized, Clinical Trial Study. Iran Red Crescent Med J. (2015) 17(12). 1

8. Joy TR, Hegele RA. Narrative review: statin-related myopathy. Ann Intern Med. (2009); 150(12):858-68.
9. Naci H, Brugts J, Ades T. Comparative Tolerability and Harms of Individual Statins. Circ Cardiovasc Qual Outcomes. (2013);6(4):390-9.

10. Stroes ES, Thompson PD, Corsini A, Vladutiu GD, Raal FJ, Ray KK, et al. Statin-associated muscle symptoms: impact on statin therapy-European Atherosclerosis Society Consensus Panel Statement on Assessment, Aetiology and Management. Eur Heart J. (2015) ;36(17):1012-22.

11. Mendes P, Robles PG, Mathur S. Statin-Induced Rhabdomyolysis: A Comprehensive Review of Case Reports. Physiother Canada. (2014) ;66(2):124-32.

12. Ramsey LB, Johnson SG, Caudle KE, Haidar CE, Voora $\mathrm{D}$, Wilke RA, et al. The Clinical Pharmacogenetics Implementation Consortium Guideline for SLCO1B1 and Simvastatin-Induced Myopathy: 2014 Update. Clin Pharmacol Ther. (2014) ;96(4):423-8.

13. Jiang F, Choi J-Y, Lee J-H, Ryu S, Park Z-W, Lee $\mathrm{J}-\mathrm{G}$, et al. The influences of SLCO1B1 and ABCB1 genotypes on the pharmacokinetics of simvastatin, in relation to CYP3A4 inhibition. Pharmacogenomics. (2017) ;18(5):459-69.

14. Mauro VF, MacDonald JL. Simvastatin: a review of its pharmacology and clinical use. DICP. (1991) ;25(3):257-64.

15. Kameyama Y, Yamashita K, Kobayashi K, Hosokawa M, Chiba K. Functional characterization of SLCO1B1 (OATP-C) variants, SLCO1B1*5, SLCO1B1*15 and SLCO1B $1 * 15+\mathrm{C} 1007 \mathrm{G}$, by using transient expression systems of HeLa and HEK293 cells. Pharmacogenet Genomics. (2005) ;15(7):513-22.

16. Piccirillo R, Demontis F, Perrimon N, Goldberg AL. Mechanisms of muscle growth and atrophy in mammals and Drosophila. Dev Dyn. (2014); 243(2):201-15.

17. Buettner C, Lecker SH. Molecular basis for statininduced muscle toxicity: implications and possibilities. Pharmacogenomics. (2008) ;9(8):1133-42.

18. Füzi M, Palicz Z, Vincze J, Cseri J, Szombathy Z, Kovács I, et al. Fluvastatin-induced alterations of skeletal muscle function in hypercholesterolaemic rats. J Muscle Res Cell Motil. (2012) ;32(6):391-401.

19. Sirvent P, Mercier J, Lacampagne A. New insights into mechanisms of statin-associated myotoxicity. Curr Opin Pharmacol [Internet]. 2008 Jun;8(3):333-8.

20. Taha DA, De Moor CH, Barrett DA, Gershkovich P. Translational insight into statin-induced muscle toxicity: from cell culture to clinical studies. Transl Res. (2014) Aug;164(2):85-109. 
21. La Guardia PG, Alberici LC, Ravagnani FG, Catharino RR, Vercesi AE. Protection of rat skeletal muscle fibers by either L-carnitine or coenzyme Q10 against statins toxicity mediated by mitochondrial reactive oxygen generation. Front Physiol.( 2013);4.

22. Wyss M, Kaddurah-Daouk R. Creatine and Creatinine Metabolism. Physiol Rev. (2000) ;80(3):1107-213.

23. Holbrook A, Wright M, Sung M, Ribic C, Baker S. Statin-Associated Rhabdomyolysis: Is There a Dose-Response Relationship? Can J Cardiol. (2011) ;27(2):146-51.

24. Auer J, Sinzinger H, Franklin B, Berent R. Muscleand skeletal-related side-effects of statins: tip of the iceberg? Eur J Prev Cardiol. (2016) 17;23(1):88-110.

25. Maghsoodi N, Wierzbicki AS. Statins: General safety profile and association with myopathy. Clin Pharm. (2016) ;8(5).

26. Sue Y-M, Chou H-C, Chang C-C, Yang N-J, Chou Y, Juan S-H. L-Carnitine Protects against Carboplatin-Mediated Renal Injury: AMPK- and PPAR $\alpha$-Dependent Inactivation of NFAT3. Singh SR, editor. PLoS One. (2014) ;9(8):e104079.

27. Oyanagi E, Yano H, Uchida M, Utsumi K, Sasaki J. Protective action of l-carnitine on cardiac mitochondrial function and structure against fatty acid stress. Biochem Biophys Res Commun]. (2011) ;412(1):61-7.

28. He M-D, Xu S-C, Lu Y-H, Li L, Zhong M, Zhang $\mathrm{Y}-\mathrm{W}$, et al. L-carnitine protects against nickel-induced neurotoxicity by maintaining mitochondrial function in Neuro-2a cells. Toxicol Appl Pharmacol. (2011) ;253(1):38-44.

29. Moosavi M, Rezaei M, Kalantari H, Behfar A, Varnaseri G. Carnitine protects rat hepatocytes from oxidative stress induced by T-2 toxin. Drug Chem Toxicol. (2016) ;39(4):445-50.

30. DiNicolantonio JJ. CoQ10 and L-carnitine for statin myalgia? Expert Rev Cardiovasc Ther. (2012); 10(10):1329-33.

31. Costa RAP, Fernandes MP, de Souza-Pinto NC, Vercesi AE. Protective effects of 1-carnitine and piracetam against mitochondrial permeability transition and PC3 cell necrosis induced by simvastatin. Eur J Pharmacol (2013) ;701(1-3):82-6.

32. Paget GE, Barnes JM. Evaluation of drug activities, In: Pharmacometrics. Lawrence DR and Bacharach AL, editors, New York :Academic press.(1964) p1: 161 .

33. Nicholls SJ, Brandrup-Wognsen G, Palmer M, Barter PJ. Meta-analysis of Comparative Efficacy of Increasing Dose of Atorvastatin Versus Rosuvastatin Versus Simvastatin on Lowering Levels of Atherogenic Lipids (from VOYAGER). Am J Cardiol. (2010);105(1):69-76.
34. Murphy SA, Cannon CP, Wiviott SD, McCabe $\mathrm{CH}$, Braunwald E. Reduction in Recurrent Cardiovascular Events With Intensive Lipid-Lowering Statin Therapy Compared With Moderate Lipid-Lowering Statin Therapy After Acute Coronary Syndromes. J Am Coll Cardiol. (2009);54(25):2358-62.

35. Rodrigues LP, Portari GV, Padovan GJ, Jordão AA, Suen V, Marchini JS. Failure of carnitine in improving hepatic nitrogen content in alcoholic and non-alcoholic malnourished rats. Clinics (Sao Paulo). (2010);65(9):877-83.

36. Shyamala MP, Venukumar MR, Latha MS. Antioxidant potential of the Syzygium aromaticum (Gaertn.) Linn. (cloves) in rats fed with high fat diet. Indian J Pharmacol. (2003);35(2):99-103.

37. Nwangwa EK, Ekhoye EI. Anti-Hyperlipidemic Activity of Aqueous Extract of Carica Papaya Seed in Albino Rats fed with High Fat Diet. (2013); 262-6.

38. Dobiaova M. Atherogenic Index of Plasma [Log(Triglycerides/HDL-Cholesterol)]: Theoretical and Practical Implications. Clin Chem. (2004); 50(7):1113-5.

39. Roeschlau P, Bernt E, Gruber W. Enzymatic determination of total cholesterol in serum. Z Klin Chem Klin Biochem (1974); 12(5):226.

40. Fossati P, Prencipe L. Serum triglycerides determined colorimetrically with an enzyme that produces hydrogen peroxide. Clin Chem. (1982); 28(10): 2077-80.

41. Burstein M, Scholnick HR, Morfin R. Rapid method for the isolation of lipoproteins from human serum by precipitation with polyanions. J Lipid Res. (1970) ; 11(6):583-95.

42. Friedewald WT, Levy RI, Fredrickson DS. Estimation of the concentration of low-density lipoprotein cholesterol in plasma, without use of the preparative ultracentrifuge. Clin Chem. (1972); 18(6):499-502.

43. Kiernan J. Histological and histochemical methods. Theory and practice. $3^{\text {rd }}$ ed. Arnold, editor. Hodder Education Publishers; (2001). P: 162-163

44. Bancroft J, Layton C. Hematoxylin and Eosin. In: Bancroft's Theory and Practice of Histological Techniques. $8^{\text {th }}$ Editio. Churchill Livingstone of El Sevier (2013). p. 172-214.

45. Kiernan J. Histological and Histochemical Methods: Theory and Practice. 4th editio. Bloxham (2008). $\mathrm{p}: 190-425$.

46. Johannessen $\mathrm{J} \mathrm{V}$. Electron Microscopy in Human Medicine,vol 1. Political Quarterly. Macgraw-Hill, New York; (1978).

47. Robinson DG, Ehlers U, Herken R, Herrmann B, Mayer F, Schürmann FW. Methods of Preparation 
for Electron Microscopy An Introduction for the Biomedical Sciences. Springer -verlag Berlin Heidelberg, New York London Paris; 1987.

48. Williams DB, Carter CB. Transmission electron microscopy. A Textbook for Materials Science. $2^{\text {nd }}$ ed. Springer-Verlag. Berlin, Heidelberg, New York and London; (1996). 721-56.

49. Moßhammer D, Schaeffeler E, Schwab M, Mörike K. Mechanisms and assessment of statin-related muscular adverse effects. Br J Clin Pharmacol (2014); 78(3):454-66.

50. Camerino GM, De Bellis M, Conte E, Liantonio A, Musaraj K, Cannone M, et al. Statin-induced myotoxicity is exacerbated by aging: A biophysical and molecular biology study in rats treated with atorvastatin. Toxicol Appl Pharmacol (2016); 306: $36-46$.

51. Janssen I, Ross R. Linking age-related changes in skeletal muscle mass and composition with metabolism and disease. J Nutr Health Aging. (2005); 9(6):408-19.

52. Rallidis LS, Fountoulaki K, Anastasiou-Nana M. Managing the underestimated risk of statin-associated myopathy. Int J Cardiol.( 2012); 159(3):169-76.

53. WACLAWIK AJ, LINDAL S, ENGEL AG. Experimental Lovastatin Myopathy. J Neuropathol Exp Neurol (1993); 52(5):542-9.

54. Westwood FR, Bigley A, Randall K, Marsden AM, Scott RC. Statin-Induced Muscle Necrosis in the Rat: Distribution, Development, and Fibre Selectivity. Toxicol Pathol (2005); 33(2):246-57.

55. Greaves P, Chouinard L, Ernst H, Mecklenburg L, Pruimboom-brees IM, Rinke M, et al. Proliferative and Non-Proliferative Lesions of the Rat and Mouse Soft Tissue, Skeletal Muscle and Mesothelium. J Toxicol Pathol. (2013); 26(3_Suppl):1S-26S.

56. Abdou HM, El Mazoudy RH. Oxidative damage, hyperlipidemia and histological alterations of cardiac and skeletal muscles induced by different doses of diazinon in female rats. J Hazard Mater (2010); 182(1-3):273-8.

57. El Rabey HA, Al-Seeni MN, Amer HM. Efficiency of Barley Bran and Oat Bran in Ameliorating Blood Lipid Profile and the Adverse Histological Changes in Hypercholesterolemic Male Rats. Biomed Res Int (2013);1-10.

58. Haschek W, Rousseaux C, Wallig M. Cardiovascular and skeletal muscle systems. In: Fundamentals of Toxicologic Pathology. 2nd ed. Academic Press, San Diego; 2010. p. 319-76.
59. Jeong W-I, Jeong D-H, Do S-H, Kim Y-K, Park H-Y, Kwon O-D, et al. Mild hepatic fibrosis in cholesterol and sodium cholate diet-fed rats. J Vet Med Sci (2005); 67(3):235-42.

60. Novitskiy G, Potter JJ, Wang L, Mezey E. Influences of reactive oxygen species and nitric oxide on hepatic fibrogenesis. Liver Int (2006); 26(10):1248-57.

61. Güler G, Türközer Z, Ozgur E, Tomruk A, Seyhan N, Karasu C. Protein oxidation under extremely low frequency electric field in guinea pigs. Effect of $\mathrm{N}$-acetyl-L-cysteine treatment. Gen Physiol Biophys (2009);28(1):47-55

62. Meza, C., Montenegro, C., De La Peña, C., O'Keefe, L., Naughton, S., Simcocks, A., ... \& Bajpeyi, S. High Fat Diet Induced Obesity Impairs Skeletal Muscle Glycogen and Lipid Preservation After Adiponectin Incubation. Int J Exerc Sci; Conference Proceedings (2017): 2 (9): 28

63. Alkharfy KM, Al-Daghri NM, Ahmed M, Yakout SM. Effects of Vitamin D Treatment on Skeletal Muscle Histology and Ultrastructural Changes in a Rodent Model. Molecules. (2012); 17(8): 9081-9.

64. Tomazoni SS, Leal-Junior ECP, Pallotta RC, De Godoi V, Rossi RP, Frigo Lú, et al. Effect of simvastatin on passive strain-induced skeletal muscle injury in rats. Muscle Nerve. (2012); 46 (6): 899-907.

65. Meregalli M, Farini A, Parolini D, Maciotta S, Torrente Y. Stem Cell Therapies to Treat Muscular Dystrophy. BioDrugs . 2010; 24 (4): 237-47.

66. Stevnes A, Lowe J. Tissue response to damage. In: Pathology. 2nd ed. Mosby; (2000). p. 35-60.

67. Mazroa SA, Asker SA. Myotoxic effects of atorvastatin drug (Lipitor) on the skeletal muscles of adult male albino rats and the effect of L-carnitine co-administration light microscopical, immunohistochemical and biochemical study. Egypt J Histol. 2010;33(3):520-31.

68. Minamoto VB, Grazziano CR and Salvini TF. Effect of single and periodic contusion on the rat soleus muscle at different stages of regeneration. Anat Rec (1999) ;254 (2): 281-7.

69. Fukushima K, Badlani N, Usas A, Riano F, Fu FH, Huard J. The Use of an Antifibrosis Agent to Improve Muscle Recovery after Laceration. Am J Sports Med . (2001);29 (4): 394-402.

70. Li Y, Huard J. Differentiation of Muscle-Derived Cells into Myofibroblasts in Injured Skeletal Muscle. Am J Pathol. (2002); 161 (3): 895-907. 
71. Al-Doaiss AA, Alarifi SA, Jarrar BM. Hepatic histological and histochemical alterations induced by rosuvastatin therapeutic doses. Pak J Zool. (2013);45(1):149-57.

72. Obayashi H, Nezu Y, Yokota H, Kiyosawa N, Mori K, Maeda N, et al. Cerivastatin induces type-I fiber-, not type-II fiber-, predominant muscular toxicity in the young male F344 rats. J Toxicol Sci. (2011); 36 (4): 445-52.

73. Grumati P, Coletto L, Sabatelli P, Cescon M, Angelin A, Bertaggia E, et al. Autophagy is defective in collagen VI muscular dystrophies, and its reactivation rescues myofiber degeneration. Nat Med (2010); 16 (11): 1313-20.

74. De Palma C, Morisi F, Cheli S, Pambianco S, Cappello $\mathrm{V}$, Vezzoli M, et al. Autophagy as a new therapeutic target in Duchenne muscular dystrophy. Cell Death Dis (2012) ; 3(11): e418-e418.

75. Ramachandran R, Wierzbicki A. Statins, Muscle Disease and Mitochondria. J Clin Med (2017); 6 (8):75.

76. Kley RA, van der Ven PFM, Olivé M, Höhfeld J, Goldfarb LG, Fürst DO, et al. Impairment of protein degradation in myofibrillar myopathy caused by FLNC/filamin C mutations. Autophagy (2013); 9 (3): 422-3.

77. Bouitbir J, Charles A-L, Echaniz-Laguna A, Kindo M, Daussin F, Auwerx J, et al. Opposite effects of statins on mitochondria of cardiac and skeletal muscles: a 'mitohormesis' mechanism involving reactive oxygen species and PGC-1. Eur Heart J [Internet]. 2012 Jun;33(11):1397-407. Available from: https:// academic.oup.com/eurheartj/article-lookup/ doi/10.1093/eurheartj/ehr224

78. Bitzur R, Cohen H, Kamari Y, Harats D. Intolerance to Statins: Mechanisms and Management. Diabetes Care [Internet]. 2013 Aug 1;36(Supplement_2):S325-30.
Available from: http://care.diabetesjournals.org/cgi/ doi/10.2337/dcS13-2038

79. Farouk AA, El-Stoohy F, El-Arab Ali S, El-Atty HA, Rashed L, Krysha NA, et al. Influence of Stem Cell Therapy on Statin-induced Myopathy of Skeletal Muscle in Female Rats. Turkish J Neurol Noroloji Derg. 2012;18(2).

80. Artioli GG, De Oliveira Silvestre JG, Guilherme JPLF, Baptista IL, Ramos GV, Da Silva WJ, et al. Embryonic stem cells improve skeletal muscle recovery after extreme atrophy in mice. Muscle Nerve (2015); 51 (3): $346-52$.

81. Murad HAS. 1-Carnitine, but not coenzyme Q10, enhances the anti-osteoporotic effect of atorvastatin in ovariectomized rats. J Zhejiang Univ B.( 2016); 17 (1): $43-53$.

82. Shehata AS, Al-Ghonemy NM, Ahmed SM, Mohamed SR. Effect of mesenchymal stem cells on induced skeletal muscle chemodenervation atrophy in adult male albino rats. Int J Biochem Cell Biol. (2017); 85: 135-48.

83. Kumaran S, Panneerselvam KS, Shila S, Sivarajan $\mathrm{K}$, Panneerselvam C. Age-associated deficit of mitochondrial oxidative phosphorylation in skeletal muscle: Role of carnitine and lipoic acid. Mol Cell Biochem (2005); 280 (1-2): 83-9.

84. Kumaran S, Subathra M, Balu M, Panneerselvam C. Supplementation of carnitine Improves Mitochondrial Enzymes in Heart and Skeletal Muscle of Aged Rats. Exp Aging Res (2005); 31 (1) :55-67.

85. Tateno K, Minamino T, Toko H, Akazawa H, Shimizu $\mathrm{N}$, Takeda S, et al. Critical Roles of Muscle-Secreted Angiogenic Factors in Therapeutic Neovascularization. Circ Res (2006); 98 (9): 1194-202. 
الملخص العربى

\section{تأثير عقار السيمفاستاتين على العضلات الهيكلية للفئران البيضاء المسنة والدور الوقائي

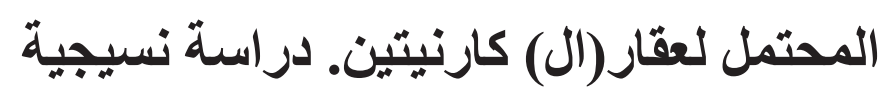

مرفت شاكر مهنا، عز الدين الشرقاوى عبد الله، فاطمة الزهراء نبيل الثـاهد، هاجر وهدان العزب

قسم الهستولوجي وبيولوجيا الخلية ـكلية الطب ـبنات - جامعة الازهر - القاهرة'، دمياط'

زيادة الدهون في الدم هو عبارة عن إضطر اب في التمثيل الغذائي وهو ما يعني زيادة غير طبيعية في مستويات الدهون (مثل الكوليسترول) والبروتين الدهني في الدم. إنه أحد عوامل الخطر التي تسبب بشكل رئيسي تصلب الثرايين وجلطات القلب و أمر اض الثر ايين التاجية والسكتة الدماغية والفتل الكلوي. يعد عقار (سيمفاستاتين) أحد أكثر الأدوية الموصوفة بشكل متكرر في جميع أنحاء العالم نظرًا لأدائه المتازفي نقص نسبة الدهون في الدم وسعره المنخفض نسبيًا. (ال ـ كارنيتين) هو مكمل غذائي يصلح لكثير من التحديات الاكلينيكية مثل عدم انتظام مستوي الدهون في الدم،

$$
\text { وفقدان الثهية و الأداء العضلي. }
$$

هدفت هذه الدر اسة إلى تقييم الدور الوقائي لـ (ال ـ كارنيتين) على العضلات الهيكلية للفئر ان التي تعاني من زيادة

$$
\text { مستوي الدهون في الدم و تعالج بـ (سيمفاستانين) }
$$

المواد والطرق: تم استخدام ثناثين من ذكور الفئر ان البيضاء المسنة ، مقسمة إلى خمس مجمو عات متساوية المجمو عة الاولي: المجموعة الضابطة و باقي المجموعات تغذت على نظام غذائي غني بالدهون لمدة ثلاثة أسابيع حتى حدوث زيادة في مستوي الدهون في الدم ،المجموعة الثانية (عالية الدهون): تغذت على نظام غذائي غني بالدهون لمدة ثلاثة أسابيع ثم تم التضحية بها ،المجمو عة الثالثة: تغذت على نظام غذائي غني بالدهون لمدة ثلاثة أسابيع ، ثم عولجت عن طريق الفم ب(سيمفاستاتين) ( 1.5 مجم / فأر / يوم) لمدة اربعة أسابيع. المجموعة الر ابعة: تغذت على نظام غذائي غني بالدهون لمدة ثلاثة أسابيع ثم عولجت عن طريق الفم ب(ال ـ كارنيتين)(20 مجم / فأر / يوم) لمدة اربعة أسابيع. المجموعة الخامسة: تغذت على نظام غذائي غني بالدهون لمدة ثلاثة أسابيع ثم عولجت بـ (سيمفاستاتين) و (ال كارنيتين) في نفس الوقت لمدة اربعة أسابيع, ثم تم أخذ العينات ومعالجنها للار اسات المجهرية الضوئية و الإلكترونية. النتائج: إعطاء (سيمفاستاتين) أدي إلي تغييرات متعددة في العضلات كفقدان الخطوط العرضية ، وتفتيت ألياف العضلات ، ووجود نواة مركزية. بينما العلاج باستخدام (ال ـ كارنيتين) أدي إلى تحسين هذه التغييرات. الخلاصة: إعطاء (ال ـ كارنيتين) أدي الي تحسين التغير ات العضلية التي حدثت نتيجة لإعطاء (سيمفاستاتين) 